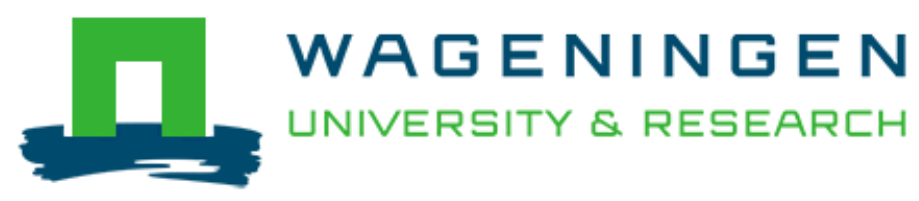

The roles of identity and brand equity in organic consumption behavior:

Private label brands versus national brands

Reinders, M. J., \& Bartels, J .

This is a "Post-Print" accepted manuscript, which has been published in "Journal of Brand Management"

This version is distributed under a non-commercial no derivatives Creative Commons (C) $(1) \Theta($ (CC-BY-NC-ND) user license, which permits use, distribution, and reproduction in any medium, provided the original work is properly cited and not used for commercial purposes. Further, the restriction applies that if you remix, transform, or build upon the material, you may not distribute the modified material.

Please cite this publication as follows:

Reinders, M. J., \& Bartels, J. (2017). The roles of identity and brand equity in organic consumption behavior: Private label brands versus national brands. Journal of Brand Management, 24(1), 68-85. DOI: 10.1057/s41262-016-0019-z

You can download the published version at:

https://doi.org/10.1057/s41262-016-0019-z 


\section{Journal of Brand Management \\ The roles of identity and brand equity in organic consumption behavior: Private label brands versus national brands --Manuscript Draft--}

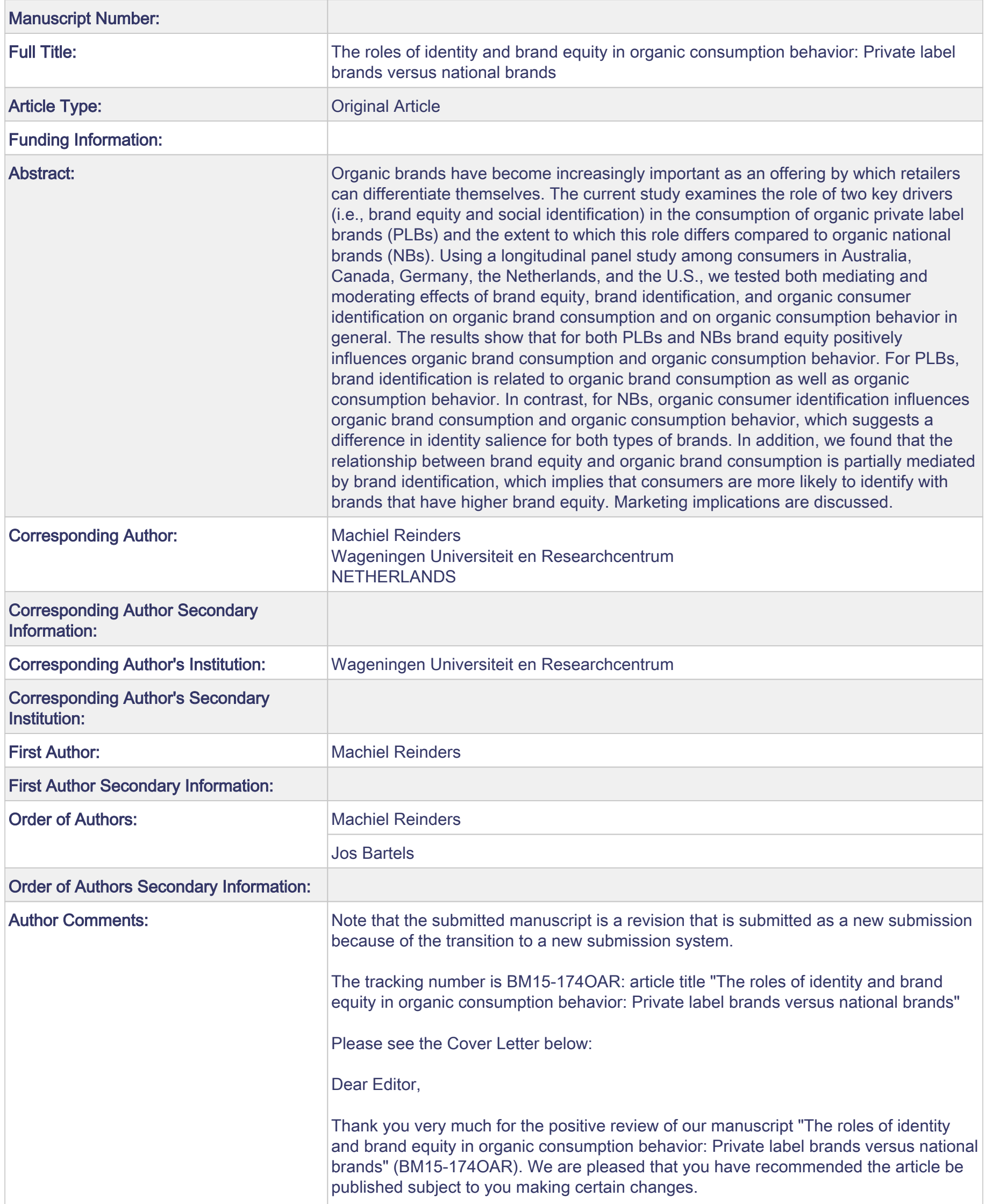


We hereby resubmit the revised manuscript. Since we did not have permission to use the images displayed in Figure 1, we decided to remove this Figure 1 from the paper. Notice that this has no further consequences for the rest of the paper, since Figure 1 was only incorporated for illustrative reasons.

Note that the contact details of one of the authors, Jos Bartels, have changed. We therefore also revised the author details and uploaded the correct ones.

We would like to thank the reviewers again for their interest in the paper and we hope that the paper in its current form lives up to the standards that are expected for the Journal of Brand Management, and we look forward to your reply. Please contact us by e-mail if you have any questions or comments.

Kind regards,

Machiel Reinders

Jos Bartels 
Title: The roles of identity and brand equity in organic consumption behavior: Private label brands versus national brands

Running title: Drivers of organic brand consumption

Machiel J. Reinders ${ }^{\mathrm{a} *}$, Jos Bartels ${ }^{\mathrm{b}}$

${ }^{a}$ Machiel Reinders (machiel.reinders@wur.nl, 0031703358104), LEI Wageningen University and Research Centre, P.O. Box 29703, 2502 LS, The Hague, The Netherlands

${ }^{b}$ Jos Bartels (j.bartels@uvt.nl), Tilburg University, Warandelaan 2, 5037 AB Tilburg, The Netherlands

*Corresponding author.

Machiel Reinders $(\mathrm{PhD})$ is a Senior Researcher Marketing and Consumer behaviour at LEIWageningen University and Research Centre. He coordinates and conducts research projects, most of which related to sustainable marketing strategies, consumer behavior with regard to sustainable and healthy food and consumer response to new products and technologies. His work has been published in several academic journals, among which Journal of Business

Research, Journal of Service Research, European Journal of Marketing, and Food Quality and Preference.

Jos Bartels (PhD), is an Assistant Professor in the Department of Communication and Information Sciences at Tilburg University, the Netherlands. His research focuses on internal and external communication, social identification processes and sustainability behavior of multiple stakeholders in organizations. He has published in several academic journals 
including Journal of Organizational Behavior, British Journal of Management, Journal of Occupational and Organizational Psychology, and Journal of Business Research. 


\title{
The roles of identity and brand equity in organic consumption behavior: Private label
} brands versus national brands

\begin{abstract}
Organic brands have become increasingly important as an offering by which retailers can differentiate themselves. The current study examines the role of two key drivers (i.e., brand equity and social identification) in the consumption of organic private label brands (PLBs) and the extent to which this role differs compared to organic national brands (NBs). Using a longitudinal panel study among consumers in Australia, Canada, Germany, the Netherlands, and the U.S., we tested both mediating and moderating effects of brand equity, brand identification, and organic consumer identification on organic brand consumption and on organic consumption behavior in general. The results show that for both PLBs and NBs brand equity positively influences organic brand consumption and organic consumption behavior.
\end{abstract} For PLBs, brand identification is related to organic brand consumption as well as organic consumption behavior. In contrast, for NBs, organic consumer identification influences organic brand consumption and organic consumption behavior, which suggests a difference in identity salience for both types of brands. In addition, we found that the relationship between brand equity and organic brand consumption is partially mediated by brand identification, which implies that consumers are more likely to identify with brands that have higher brand equity. Marketing implications are discussed.

Key words: Organic; Private label brand; National brand; Brand equity; Brand identification; Organic consumer identification; Brand consumption 


\section{Introduction}

Retailers increasingly use their own brands (i.e., private label brands) as a way to differentiate themselves from their competitors (Cuneo et al, 2015; González-Benito and Martos-Partal, 2012; Sethuraman and Gielens, 2014). As a consequence, the market shares of private label brands (PLBs) are growing in almost all European and U.S. markets. For example, the market shares of PLBs in the food and beverage industry in 2013 ranged from 18 percent in the U.S. to 42 percent in Germany (Statista, 2014). Consumers indicate that they prefer PLBs over national brands (NBs) and that many PLBs are equally as good as—or better than - their favorite NBs (Deloitte, 2015). This preference is reflected in the fact that PLBs have moved from low priced "me-too" products to high-quality brands (Grewal and Levy, 2009). At the end of the 1990s, strong national retailers such as Wal-Mart began to put innovative, good quality private brands on the market. In recent years, we have observed many retailers following this initiative. By increasing the quality of PLBs, retailers can increase profit margins by charging higher prices (Steenkamp et al, 2010).

This trend is also reflected in the fact that retailers are now increasingly incorporating environmental and social issues in their PLBs (Aouina Mejri and Bhatli, 2014; Chkanikova and Lehner, 2015; Gleim et al, 2013). One of the ways to accomplish this is by adding an organic label to a PLB. Organic (food) products carry an organic certification that is issued by an independent accredited institution for organic product testing (Bauer et al, 2013). The market for organic products has increased substantially over the last years (Willer and Kilcher, 2010). For example, sales of organic food and non-food products in the U.S. reached a record of \$39.1 billion in 2014 (Organic Trade Association, 2015). Moreover, in 2012, 81\% of U.S. families reported that they purchase organic products at least occasionally (Organic Trade Association, 2013). Organic PLBs have become increasingly important as an offering by which retailers differentiate themselves (Jonas and Roossen, 2005). Retailers can use 
brands that are labelled with the organic logo to boost perceived product quality (Larceneux et $51 a l$, 2012). Ngobo (2011) showed that households are more likely to buy organic PLBs than their national counterparts. In addition, a recent study by Bauer et al (2013) investigated the effect of organic labels on brands and found that private labels benefit more from the use of organic labels than global brands. It is therefore not surprising that many retailers have developed their own organic PLBs. For example, in the U.S., Whole Foods Market launched its own organic products under the label '365 Everyday Value' and the German retail chain Edeka uses 'Edeka Bio' as its private label.

Despite the strong position that an organic label can provide to PLBs, organic labels have also proven to be an effective instrument for NBs in distinguishing their own brand from that of their competitors (Bauer et al, 2013). Given the increasing importance of organic brands for both brand manufacturers and retailers, the current study examines the role of a number of key constructs in the consumption of organic PLBs and organic NBs. First, we will explore whether brand equity also affects brand consumption in an organic context. In an organic (food) context, we define brand consumption as the number of times a brand is eaten or drunk. Brand equity can be defined as "the incremental utility or value added to a product by its brand name" (Yoo et al, 2000, p. 195). Previous studies have shown that brand equity is an important predictor of the purchase (intention) of brands (Cobb-Walgren et al., 1995; Keller, 1993). These effects are also found in a 'green' context (Bekk et al, 2016; Konuk et al, 2015). We extend these studies by examining whether brand equity also predicts consumption of brands in an organic context. Next, we try to further elaborate on how brand equity may relate to brand consumption in an organic context by stuyding the roles of brand identification and identification with the group of organic consumers. Brand identification refers to the degree of a brand's ability to integrate the brand into the consumer's self-concept (Escalas \& Bettman, 2003), thus helping consumers to define themselves. In the organic context, we 
expect that in addition to identification with a brand identification with the group of consumers also plays a role in stimulating the consumption of a brand. In this respect, we define organic consumer identification as consumer's perception of oneness or belongingness to the group of organic consumers (Bergami and Bagozzi, 2000). Due to the distinctive

features that are associated with organic products relative to conventional products (e.g., they are environmentally friendly and chemical free), organic consumption is an attractive target for consumers to express their self-definition (i.e., who am I?) and to enact their identity (Ashforth and Mael 1989). In particular, the identity of organic consumers as a group is growing in popularity and carries rich and positive connotations (Hughner et al 2007). In this respect, Schifferstein and Oude Ophuis (1998) state that organic consumption is part of a way of life. Indeed, recent studies suggest that consumers' identity-related beliefs exert a significant positive impact on their decision to purchase organic products (Bartels and Reinders 2010; Dean et al 2012).

Furthermore, we investigate whether in an organic context positive brand equity and identification spill over to the consumption of other organic products. In this respect, Bartels and Hoogendam (2011) found that positive evaluations of a specific brand led to more positive buying behavior for organic foods in general.

Finally, we will investigate whether the proposed mechanism between brand equity, brand identification, organic consumer identification, organic brand consumption and general organic consumption differs between organic PLBs and organic NBs. Although many studies are devoted to comparing PLBs and NBs (Ailawadi et al, 2001; De Wulf et al, 2005; Steenkamp et al, 2010), research that compares these two types of brands in an organic context has been limited. More specifically, most studies in a regular context focus on the difference in price perceptions between NBs and PLBs (e.g., Olbrich and Jansen, 2014; Steenkamp et al, 2010), while in an organic context this discussion does not seem to focus on 
100

price differences between NBs and PLBs but rather on price differences between regular and organic products (e.g., Aschemann-Witzel and Zielke, 2015; Rödiger and Hamm, 2015). Similarly, several studies in a regular context focus on quality variations between PLBs and NBs (e.g., De Wulf et al, 2005; Mieres et al, 2006), while in an organic context this discussion seems to focus more on quality comparisons between regular and organic products (e.g., Larceneux et al., 2012). In sum, most studies in an organic context focused on comparing organic with regular products and not on comparing organic PLBs with organic NBs. As a result, no studies have examined whether drivers of the consumption of PLBs and NBs may systematically differ in an organic context.

In sum, the current study aims to empirically explore the following research questions: How is brand equity related to brand consumption in an organic branding context? What is the role of social identification in this relationship? Do these effects spill over to organic consumption in general? and To what extent do these relationships differ for PLBs and NBs?

To answer these questions, we used a cross-country research design and tested both the direct and indirect (i.e., mediating and moderating) effects of brand equity, brand identification, and organic consumer identification on organic brand consumption and on organic consumption in general. Before introducing the method and results of this study, we first briefly review the literature concerning the key constructs of our study.

\section{Literature Review}

\section{Brand equity and organic branding}

To increase the perceived value of organic products, branding has become an important marketing strategy. A key construct that is often mentioned with regard to branding is brand equity (Esch et al 2006; Netemeyer et al, 2004). According to Yoo et al (2000, p. 
195), brand equity is the "incremental utility or value added to a product by its brand name." Aaker (1991) defined brand equity as "a set of brand assets and liabilities linked to a brand, its name and symbol that add to or subtract from the value provided by a product or service to a firm and to the firm's customers." In addition, Keller (1993) posited that brand equity can create the differential effect of a brand relative to other brands. The existing literature has also measured brand equity in the context of PLBs. For example, Erdem et al (2004) found that brand equity plays an important role in consumers' private label brand choices and seems to have a variety of impacts on PLBs. In addition, Cuneo et al (2012) found that private label brand equity varies across different products and markets. More recently, Calvo-Porral et al (2015) found that brand equity dimensions (i.e., awareness, perceived quality and loyalty) were positively related to purchase intention for PLBs. From these studies we can conclude that brand equity plays an important role in the evaluation and purchase of both NBs as well as PLBs.

Within the academic literature, an increasing number of studies have focused on the topic of green branding (e.g., Gupta and Kumar, 2013; Hartmann et al, 2005; Pickett-Baker and Ozaki, 2008). For example, a number of studies have investigated the factors that influence the consumer purchasing behavior of green brands (Papista and Krystallis, 2013) and the roles of brand knowledge and attitudes (Bartels and Hoogendam, 2011). As a result, recent studies have also extended the brand equity research into the environmental context by introducing the concept of "green brand equity" (Bekk et al, 2016; Chen, 2010; Kang and Hur, 2011; Ng et al, 2013). This concept can be defined as "a set of brand assets and liabilities about green commitments and environmental concerns linked to a brand, its name and symbol 147 that add to or subtract from the value provided by a product or service." (Chen, 2010, p. 310). 148 These studies have especially focused on the antecedents of green brand equity, i.e., the 149 aspects that drive brand equity for 'green' or eco-friendly brands. For example, Chen (2010) 
demonstrated that green brand image, green satisfaction, and green trust are positively related to green brand equity. Additionally, Kang and Hur (2011) investigated green affect and green loyalty, and Chang and Chen (2013) explored the relationship between green perceived quality, green brand awareness, and green perceived risk in the building of green brand equity. Recently, Bekk et al (2016) and Konuk et al (2015) presented the first empirical evidence that green brand equity also influences brand outcomes (i.e., purchase intentions and positive word-of-mouth communication).

While the previous research has cautiously begun to focus on brand equity in a green context, to the best of our knowledge there are no studies that pay attention to how the sbrand equity of organic brands affects their consumption. For organic products, brand equity could both reflect the equity of the brand itself as well as the equity that is obtained by the organic labels that are carried by these products (Larceneux et al, 2012). Although organic products are a type of product that is sold under many brand names, the concept itself also offers a strong and differentiated advantage as compared with products that do not carry an organic label. In this respect, Stanton and Guion (2015) posit that the organic concept could be regarded as being akin to a brand. Consequently, it is useful to explore how consumers might affiliate with this overall concept of organic, apart from brand equity. More specifically, this relationship between an individual and the organic concept could be best explained by investigating how individuals perceive other individuals or groups that consume organic products.

\section{Social identification}

A concept for explaining a relationship between an individual and a group is social identification (Tajfel, 1978; Tajfel and Turner, 1979). Social identification refers to "the perception of oneness with or belongingness to a group, where the individual defines him or 
175 herself in terms of the group of which he or she is a member" (Mael and Ashforth, 1992, p.

104). Many studies have confirmed the relevance of strong identification in an organizational context (Mael andAshforth, 1992; Van Dick et al, 2004), marketing context (Bhattacharya et al, 1995; Bhattacharya and Sen, 2003; Homburg et al, 2009), brand community context (Algesheimer et al, 2005; Bagozzi and Dholakia, 2006; Dholakia et al, 2004) and, more recently, in a sustainable consumption context (Bartels and Hoogendam, 2011; Bartels and Reinders, 2010). For example, Bartels and Reinders (2010) found that social identification was strongly related to organic food consumption. In addition, Bartels and Hoogendam (2011)

showed that in addition to brand knowledge and brand attitude, social identification with green consumer groups had distinct indirect and direct effects on buying behaviors with respect to organic foods. Consequently, we expect that identification with organic consumer groups plays an important stimulating role in the consumption behavior of organic brands. Based on insights from social identity theory, a growing body of research has also focused on what it means for consumers to identify with brands as a consumer-brand relationship construct (Escalas and Bettman, 2003; Stokburger-Sauer et al, 2012). Because consumer-brand identification involves affective attachment with a brand, consumers with stronger brand identification are more likely to evaluate the value of a brand more favorably (He et al, 2012). Brand identification positively affects brand commitment (Tuškej et al, 2013), brand passion (Albert et al, 2013) and brand loyalty (Lam et al, 2010). In turn, brand passion was also found to have a direct effect on word-of-mouth and an indirect effect on the willingness to pay a higher price. Because recent research shows that consumers' identification with a brand plays an important role in the evaluation of the brand, in the current study, we investigate the role of brand identification in the relationship between brand equity and organic brand consumption. 
In sum, we aim to empirically clarify how brand equity, organic consumer

identification and brand identification are related to brand consumption for PLBs and NBs.

By doing so, we distinguish between identification with organic consumer groups (i.e., organic consumer identification) and consumer-brand identification with organic brands (i.e., brand identification). Accordingly, we test different models in which we incorporate both the direct and indirect (i.e., mediating and moderating) effects of organic consumer identification and brand identification on organic consumption.

\section{Method}

\section{Procedure}

We conducted a longitudinal online panel study among consumers in five globally dispersed countries (i.e., Australia, Canada, Germany, the Netherlands, and the U.S.).

Participants were approached by email to fill out an online self-administered questionnaire.

The data were collected by a market research agency (MSI-ACI Europe BV). The respondents completed questions on brand equity, brand identification, identification with organic consumers, brand consumption and organic consumption in general. The market research agency translated the original English items of the questionnaire into the relevant national languages. We collected data on brand consumption and organic consumption in general more than a year later to reduce common method variance and increase the validity of the dependent variables (Podsakoff et al, 2003). The data were collected in December 2010 (T1) and in February 2012 (T2). In total, 1,584 respondents completed the questionnaire at T1, and 706 of these respondents also completed the questionnaire at T2. Only the respondents who completed questionnaires at both $\mathrm{T} 1$ and $\mathrm{T} 2$ (within-subjects design) were included in the analyses. Furthermore, for each country, the respondents received questionnaires that featured either a PLB or NB. For each country, we used one NB and one or two PLBs. We selected the 
227

PLBs from retailers that are most well-known in every country. The respondents randomly received one of these brands to evaluate. This process resulted in 404 respondents for PLBs and 302 respondents for NBs.

\section{Sample}

We instructed the market research agency that our study samples should be representative of the specific country in terms of age, gender, education and income distribution at T1. The total sample was composed of 354 males and 352 females with a mean age of 49.5 years $(\mathrm{SD}=14.8)$. Overall, $18.6 \%$ of the respondents had a low educational level, $47.5 \%$ had a moderate educational level, and $34.0 \%$ had a high educational level. With regard to income, $25.6 \%$ of the respondents reported a low income level, $32.0 \%$ reported a medium income level, and 30.6\% reported a high income level. A percentage of $11.8 \%$ of the respondents did not want to report their income. Table 1 provides a description of the sample in each of the countries. As shown in the table, organic consumption behavior differs between the countries. Organic consumption is highest in Germany and lowest in Australia and the U.S. Consumption of the specific organic brands that the respondents received (depending on the country and the condition of the questionnaire) also differed per country. Overall, brand consumption is found to be highest in Canada and lowest in the U.S. and Australia. In addition, differences are observed between the consumption of PLBs and NBs, whereby in most cases consumption of PLBs seems to be higher. 
The questionnaire covered a number of topics at T1 and T2. Brand equity, brand identification, identification with the organic consumer and organic product familiarity were measured at T1. Organic brand consumption and organic consumption behavior were measured at T2. Brand equity at T1 was operationalized as constituting the dimensions brand awareness, perceived quality and brand loyalty (cf. Yoo and Donthu, 2001) and was measured for the PLBs and NBs, depending on the condition of the questionnaire. We measured the construct on a 5-point Likert scale using three items. An example item is, "The likely quality of this brand is very high.” The reliability of the scale was adequate for both PLBs and NBs (Cronbach's $\alpha=.79$ and .83 , respectively). Brand identification at T1 was operationalized as the degree of overlap between the self-definition and the identity of the brand as measured by Bergami and Bagozzi's (2000) visual scale to assess identification. The respondents choose the number that corresponded to the pair of circles (1="far apart," $2=$ "small overlap," $3=$ "moderate overlap," 4= "large overlap," 5= "complete overlap") that best reflect the degree of overlap they perceive between their own identity and that of the brand. Likewise, organic consumer identification describes the degree of overlap between the self and the group of organic consumers and was also measured with Bergami and Bagozzi's (2000) visual scale. 264 The respondents choose the number that corresponded to the pair of circles $(1=$ "far apart," $2=$ 265 "small overlap," 3= "moderate overlap," 4= "large overlap," 5= "complete overlap") that best 266 reflect the degree of overlap that they perceive between their own identity and the identity of 267 the organic consumer. Because organic brands are not well-known to the general public 268 (compared to regular food and beverage brands, e.g., Coca-Cola) and familiarity with a 269 product seems to be important in predicting consumption behavior (Alba and Hutchinson, 270 1987; Biswas, 1992), we incorporated organic product familiarity as a control variable. We 271 used 4 items based on Yoo et al (2000) and adapted them to the organic product domain, with 

296

sample items such as, "I can recognize organic products among other regular brands" and

"Some characteristics of organic products come to my mind quickly" (Cronbach's $\alpha=.72$ for PLBs and .72 for NBs). Organic brand consumption at T2 was measured with the following single item: "How often did you eat or drink Brand X in the last month?" The scale ranged from 1 (never) to 5 (five times a week or more). What was exactly mentioned under "Brand X" was dependent on the version of the questionnaire that the respondent received (i.e., PLB or NB) as well as on the country of the respondent. Organic consumption behavior was measured by asking the respondents to indicate how often they ate organic meat, vegetables, fruit, and dairy products following Onwezen et al (2014) on a five-point scale (ranging from $1=$ 'never' to 5 = 'five times a week or more'). Note that, compared to organic brand consumption, this question was the same for all of the respondents that participated in the study, regardless of the version of the questionnaire (i.e., PLB or NB) or country. The Cronbach's alphas were 90 for PLBs and .91 for NBs. Finally, demographic variables (i.e., item scales were averaged across their scale items to create composite construct scores.

\section{Results}

The respondents who completed the questionnaire for PLBs $(N=404)$ awarded the highest average scores to organic product familiarity $(M=3.06 ; \mathrm{SD}=.82)$ and the lowest to organic brand consumption $(M=1.73 ; \mathrm{SD}=.98)$. In addition, all of the independent and dependent variables were positively correlated $(p<.01)$. The respondents who completed the questionnaire for NBs $(N=302)$ also gave the highest average scores to organic product familiarity $(M=3.05 ; \mathrm{SD}=.82)$ and the lowest to organic brand consumption $(M=1.62 ; \mathrm{SD}$ $295=.95)$. Again, all of the independent and dependent variables were positively correlated $(p<$ .01). We compared the means for both samples and found that the mean for brand equity was 
significantly higher for PLBs $(M=2.74)$ than it was for NBs $(M=2.58 ; t=1.99, \mathrm{df}=704, p$ $<.05)$. The Fisher's Z-tests revealed significant differences between PLBs and NBs for the correlations of organic consumption behavior with organic brand consumption $(z=-3.07, p<$ $.01)$, the correlations of organic consumer identification with organic brand consumption $(z=$ $-2.15, p<.05)$ and the correlations of organic product familiarity with organic brand consumption $(z=-2.22, p<.05)$. In all of the cases, correlations are stronger for NBs compared to PLBs. Table 2 displays the means, standard deviations and correlations for both samples.

\section{-- INSERT TABLE 2 HERE--}

\section{Model testing}

We conducted multiple regression analyses to answer the research questions. First, we tested the direct effects of brand equity on organic brand consumption (Model 1). Then, we estimated the simultaneous effects of brand equity, brand identification and organic consumer identification on organic brand consumption (Models 2 and 3). In Model 4, we tested whether brand identification and organic consumer identification moderate the relationship between brand equity and organic brand consumption. Finally, we tested whether these effects also hold for general organic consumption behavior as a dependent variable (Models 5 to 8). We also included organic product familiarity in all of the models as a control variable.

Additionally, we performed a mediation analysis by conducting Preacher and Hayes's (2008) bootstrap analysis of indirect effects to test whether the relationships between brand equity and organic brand consumption, on the one hand, and brand equity and organic consumption behavior, on the other hand, were mediated by brand identification and identification with the organic consumer. Before conducting the analyses, we first centered the means of all of the 
variables for both private label and NBs. Tables 3 and 4 list the estimation results of the models for both PLBs and NBs. The various countries were incorporated as dummy variables in the analyses.

\section{Private label brands}

Table 3 displays the results of the regression analyses for PLBs. Brand equity showed a positive direct effect on organic PLB consumption (Model $1: \beta=.43 ; p<.01$ ). None of the control variables (i.e., demographics and countries) were significant. When brand equity and brand identification were simultaneously regressed on organic brand consumption in Model 2, the coefficient of brand equity decreased somewhat $(\beta=.29 ; p<.01)$, while the coefficient of brand identification was found to be significant $(\beta=.24 ; p<.05)$. These results are indicative of a partial mediating role of brand identification in the relationship between brand equity and brand consumption for organic PLBs. To test this more formally, we performed a mediation analysis following the procedure of Preacher and Hayes's (2008) bootstrap analysis of indirect effect, using 5,000 bootstrap samples. Our bootstrap analysis showed that the indirect effect of brand equity on organic brand consumption through brand identification is positive and significant (estimated effect $=.14$ ), with a $95 \%$ bias-corrected bootstrap confidence interval excluding zero (.07 to .24). In addition, Model 3 shows that adding organic consumer identification to the model did not lead to a significant improvement of the model. Finally, Model 4 shows that the moderating effects between brand equity and brand identification and between brand equity and organic consumer identification on organic brand consumption were insignificant.

Model 5 shows that for NBs, brand equity had a positive direct effect on generic organic consumption behavior $(\beta=.31 ; p<.01)$. In contrast to the previous models, organic product familiarity also had a significant effect on generic consumption $(\beta=.30 ; p<.01)$. 
347 When brand equity and brand identification were simultaneously regressed on generic organic

consumption behavior in Model 6, the coefficient of brand equity decreased somewhat $(\beta=$ $.16 ; p<.01)$, while the coefficient of brand identification was also found to be significant $(\beta=$ $.26 ; p<.01)$. These results are indicative of a partial mediating role of brand identification in the relationship between brand equity and generic organic consumption behavior. A bootstrap analysis using 5,000 bootstrap samples (Preacher and Hayes, 2008) showed that the indirect effect of brand equity on generic organic consumption behavior through brand identification is positive and significant (estimated effect $=.16$ ), with a $95 \%$ bias-corrected bootstrap confidence interval excluding zero (.08 to .25$)$. When adding organic consumer identification to the model (Model 7), we see that brand equity remained a significant predictor $(\beta=.16 ; p<$ $.01)$, while the significance of brand identification decreased somewhat $(\beta=.16 ; p<.05)$ at the expense of organic consumer identification $(\beta=.19 ; p<.01)$. This could imply a partial mediating role of organic consumer identification in the relationship between brand identification and generic organic consumption behavior. We again performed a bootstrap analysis of indirect effect, using 5,000 bootstrap samples, which showed that the indirect effect of brand identification on generic organic consumption behavior through organic consumer identification is positive and significant (estimated effect $=.10$ ), with a $95 \%$ biascorrected bootstrap confidence interval excluding zero (.03 to .19). Finally, in Model 8, we found that the moderating effects between brand equity and brand identification and between brand equity and organic consumer identification were also insignificant for generic organic consumption behavior.

\section{National brands}


Table 4 displays the results of the regression analyses for NBs. Brand equity showed a positive direct effect on organic brand consumption (Model 1: $\beta=.40 ; p<.01$ ). Interestingly, organic product familiarity also had a positive significant effect on organic brand consumption $(\beta=.23 p<.01)$ in the NB condition. When brand equity and brand identification were simultaneously regressed on organic brand consumption (Model 2), the coefficient of brand equity decreased somewhat $(\beta=.27 ; p<.01)$, while the coefficient of brand identification was found to be significant $(\beta=.22 ; p<.01)$. Again, these results could be indicative of a partial mediating role of brand identification in the relationship between brand equity and brand consumption for organic NBs. To test this outcome more formally, we again conducted a mediation analysis using 5,000 bootstrap samples. The results of this bootstrap analysis showed that the indirect effect of brand equity on organic brand consumption through brand identification is positive and significant (estimated effect $=.12$ ), with a $95 \%$ bias-corrected bootstrap confidence interval excluding zero (.02 to .21$)$. Model 3 shows that when adding organic consumer identification to the model, brand equity remained a significant predictor $(\beta=.27 ; p<.01)$, while brand identification became insignificant at the expense of organic consumer identification $(\beta=.16 ; p<.05)$. This could imply a full mediating role of organic consumer identification in the relationship between brand identification and organic brand consumption. However, a bootstrap analysis with 5,000 bootstrap samples showed that for the indirect effect of brand identification on organic brand consumption through organic consumer identification, the $95 \%$ bias-corrected bootstrap confidence interval straddles zero. This implies that there is no mediation. Finally, Model 4 shows that the moderating effects between brand equity and brand identification and between 394 brand equity and organic consumer identification on organic brand consumption were 395 insignificant. 
Model 5 shows that both brand equity $(\beta=.33 ; p<.01)$ and product familiarity $(\beta=$ $.34 ; p<.01)$ were significant predictors of generic organic consumption behavior. When brand equity and brand identification were simultaneously regressed on generic organic consumption behavior in Model 6 , the coefficient of brand equity decreased somewhat $(\beta=$ $.20 ; p<.01)$, while the coefficient of brand identification was also found to be significant $(\beta=$ $.21 ; p<.01)$. These results are indicative of a partial mediating role of brand identification in the relationship between brand equity and brand consumption for generic organic consumption behavior. A bootstrap analysis using 5,000 bootstrap samples showed that the indirect effect of brand equity on generic organic consumption behavior through brand identification is positive and significant (estimated effect $=.12$ ), with a $95 \%$ bias-corrected bootstrap confidence interval excluding zero (.04 to .20). When adding organic consumer identification to the model (Model 7), we see that brand equity remained a significant predictor $(\beta=.20 ; p<.01)$, while brand identification became insignificant, and organic consumer identification became a significant predictor $(\beta=.31 ; p<.01)$. This could imply a full mediating role of organic consumer identification in the relationship between brand identification and generic organic consumption behavior. Indeed, a bootstrap analysis of indirect effect, using 5,000 bootstrap samples, showed that the indirect effect of brand identification on generic organic consumption through organic consumer identification is positive and significant (estimated effect $=.17$ ), with a $95 \%$ bias-corrected bootstrap confidence interval excluding zero (.09 to .27). Finally, in Model 8, we found that the moderating effects between brand equity and brand identification and between brand equity and organic consumer identification were also insignificant for generic organic consumption behavior. 


\section{Discussion}

Organic brands have been gaining significant momentum over the past several years.

This study was one of the first studies that investigated the role of brand equity and social identification in the context of organic branding. By doing so, we compared organic PLBs with organic NBs. This study yields several key findings, which will be discussed below.

First, as expected, brand equity positively influences organic brand consumption for both PLBs and NBs. This is in line with a vast amount of studies that found that brand equity plays an important role in brand consumption behavior (e.g., Cobb-Walgren et al., 1995; Keller, 1993). The results of this study extend the previous research by showing that in an organic context, the brand equity of a specific organic brand also enhances generic organic consumption. These findings seem to be in contrast with a non-organic, regular context. For example, in a regular context, a positive evaluation of a brand such as Coca-Cola does not necessarily lead to more consumption of other cola or soda brands in general. This relationship between brand equity and general organic consumption behavior could be explained by possible spillover effects. In this context, Bartels and Hoogendam (2011) found moderate to strong positive relationships between attitude towards a specific organic brand and buying behavior for organic food.

Second, the current study confirms the importance of multiple identities in explaining behavior (Ashforth and Johnson, 2001; Pratt and Foreman, 2000). Previous studies in a green context have already found that multiple social identities play a role in explaining different environmentally friendly behaviors (Bartels and Reinders, 2016; Murtagh et al, 2012). In addition to these studies, the current study showed that the role of multiple identities on adjacent behaviors also depend on the type of product or brand that is at stake. More precisely, the role of brand identification and organic consumer identification in predicting 
both organic brand consumption and general organic consumption behavior differs for PLBs 447 compared to NBs. For PLBs, brand identification is related to organic brand consumption as 448 well as organic consumption behavior in general. In contrast, for NBs, brand identification is 449 no longer related to organic brand consumption and general organic consumption behavior 450 when controlling for organic consumer identification. Further, the role of organic consumer 451 identification seems to differ for PLBs compared to NBs. For PLBs, identification with 452 organic consumers does have a positive impact on organic consumption behavior in general, 453 but it does not influence the consumption behavior for that particular brand. In contrast, 454 concerning NBs, identification with organic consumers also leads to an increase in 455 consumption of the brand. Tapping the concept of identity salience ${ }^{1}$ (Arnett et al, 2003; 456 Stryker and Burke, 2000), consumers' identity salience could differ between organic PLBs 457 and organic NBs. Under the PLB condition, the identity of the brand could be more salient, 458 while under the NB condition, the identity of the green or sustainable consumer (i.e., the 459 greenness of the concept) could be more salient. This difference in identity salience could explain why brand identification and organic consumer identification seems to have different roles for PLBs and NBs.

Third, based on the results from the current study, we can conclude that identification also plays a role in explaining the relationship between brand equity and consumption behavior. On the one hand, for both PLBs and NBs, this relationship was not strengthened or weakened by brand identification or organic consumer identification (i.e., moderation). On the other hand, the relationship between brand equity and consumption behavior of that brand is partially determined by identification with the brand or organic consumer group (i.e., mediation). Social identity theory states that consumers want to identify with groups or brands that have high status and positive publicity (Kuenzel and Halliday, 2008). Because brand

\footnotetext{
${ }^{1}$ Identity salience can be defined as the probability that an identity will be invoked across a variety of situations, or alternatively across persons in a given situation (Stryker and Burke, 2000, p. 286).
} 
equity is related to the quality and status of a brand, it logically follows that consumers are more likely to identify with brands that have higher brand equity, and they are subsequently more likely to buy these brands. Moreover, brand identification seems to lead to stronger organic consumer identification. This could imply that in the case of a specific concept such as organic products, attractive features of a brand could positively reflect on the group of organic consumers. As a result, positive identification with the brand also leads to stronger identification with the group that adheres to this concept (i.e., organic consumers), which indicates so-called 'nested identities' (Ashforth and Johnson, 2001).

Fourth, we found a distinguishing role of organic product familiarity between organic PLBs and organic NBs. For PLBs, organic product familiarity does not affect the consumption of the brand. A possible explanation for this effect is that the purchase and consumption behavior of organic PLBs is more likely to be related to familiarity with the retailer and its brands than to familiarity with organic products in general. In contrast, for NBs, there is a clear relationship between organic product familiarity and brand consumption.

Organic product familiarity could then be one of the drivers of brand consumption.

Finally, the results of this study are robust, given that the effects were tested in a variety of countries with different levels of consumption of organic brands and organic products in general. This study therefore meets the requirement of cross-validation for a better understanding of consumer behavior (Steenkamp and Baumgartner, 1998). Moreover, temporarily separating the measurement of the independent variables and dependent variables allows us to reduce biases in consumers' self-reported responses by making prior responses less salient (Podsakoff et al, 2003).

\section{Marketing implications}


The results of the current study offer some interesting marketing implications. The current study shows that building successful organic brands could pay off for retailers as well as brand manufacturers. Building brand equity for organic brands seems to stimulate brand purchases for both PLBs and NBs. This recommendation is relevant given that organic brands are gaining in importance (Organic Trade Association, 2015). The sale of specific organic brands expectedly has spillover effects to other organic products. Thus, creating good quality brands and selling them in attractive stores could help to enhance the market for organic products in general. Although in the short term this seems not to be in the interests of brand managers, they could potentially benefit from a more developed organic market because higher market shares for organic products in general could also stimulate sales of their own organic brands.

In addition, for both organic PLBs and NBs, brand identification plays a crucial role in enhancing consumer demand for brands. For both retailers and brand manufacturers, brand identification can be used as a catalyst to improve the sales of organic brands. More specifically, the results of the current study imply that brand managers can use the principles of 'basking in reflected glory' to boost the sales of their brands (Cialdini et al, 1976). For example, brand managers may activate consumers' status motives by linking their organic brands with visible status (e.g., prestigious events) (Griskevicius et al, 2010).

Apart from these similarities between organic PLBs and organic NBs, there are also differences to which brand managers should pay attention. For NBs, managers should focus more on organic consumer identification in general. For example, communicating that it is 'cool' to be part of a green consumer group. For PLBs, managers should focus more on brand 516 identification. For example, managers can try to enhance consumers' sense that the brand 517 boosts their status and therefore their self-esteem. 


\section{Limitations and directions for future research}

520 This study has several limitations that could be addressed in future research. First, this study does not make a distinction between different types of PLBs based on the underlying characteristics of the retailer that is offering the brand. As the retail landscape is rather diverse, ranging from hard-discount to luxury stores, and a retailer's price positioning has been shown to influence private label brand consumption (González-Benito and MartosPartal, 2012), future research could further elaborate on the evaluation of organic private label brands based on these retailer differences. Similarly, there are a number of differences in how private label brands are labelled. For example, some private label brands bear the name of the retailer (e.g., 'Edeka Bio' from Edeka), whereas other private label brands bear their own name (e.g., ‘365 Everyday Value’ from Whole Foods Market). The type of labelling could also influence how organic private label brands are evaluated and, therefore, represents another research opportunity.

Second, we focused on organic food. Although food products constitute an important product category in the context of retailing, future research could focus on non-food categories such as organic apparel or personal care products. For example, organic apparel has not only proven to be a promising growth market (Textile Exchange, 2014), but also could be a consequence of potential spill-over effects. In this respect, a recent study by Ellis et al (2012) showed that consumers who had previously purchased organic foods were willing to pay more for organic apparel, thus suggesting the presence of spill-over effects.

Third, the findings for organic NBs seem to be somewhat in contrast to a regular context. For example, in a regular context, a positive evaluation of the Coca-Cola brand does not necessarily lead to more consumption of other cola brands in general. Future research could elucidate to what extent it will be more difficult for organic brands to compete with each other compared to how brands in a regular context compete (e.g., Coca-Cola versus 
544 Pepsi Cola) and the consequences for future organic brand marketing strategies. In addition,

1

2 3

9 10
545 little is known about the way in which the consumption of PLBs and NBs may complement rather than substitute each other (Sethuraman and Gielens, 2014). A recent a study by

547 Krystallis (2015) found that in certain situations, consumer motivation could be equal for both 548 PLBs and NBs, thus suggesting some degree of complementarity. Future research endeavors 549 could focus on this complementarity for organic and other green brands. 


\section{References}

Aaker, D. (1991). Managing Brand Equity: Capitalizing on the Value of a Brand Name. Free Press, New York, NY.

Ailawadi, K.L., Neslin, S.A., and Gedenk, K. (2001). Pursuing the value-conscious consumer: Store brands versus national brand promotions. Journal of Marketing, 65, 71-89.

Alba, J.W., and Hutchinson, J.W. (1987). Dimensions of consumer expertise. Journal of consumer research, 411-454.

Albert, N., Merunka, D., and Valette-Florence, P. (2013). Brand passion: antecedents and consequences. Journal of Business Research, 66(7), 904-909.

Algesheimer, R., Dholakia, U.M., and Herrmann, A. (2005). The social influence of brand community: Evidence from European car clubs. Journal of Marketing, 69(3), 19-34.

Aouina Mejri, C., and Bhatli, D. (2014). CSR: Consumer responses to the social quality of private labels. Journal of Retailing and Consumer Services, 21(3), 357-363.

Arnett, D.B., German, S.D., and Hunt, S.D. (2003). The identity salience model of relationship marketing success: The case of non-profit marketing . Journal of Marketing, 67(2), 89-105.

Aschemann-Witzel, J., and Zielke, S. (in press). Can't Buy Me Green? A Review of Consumer Perceptions of and Behavior Toward the Price of Organic Food. Journal of Consumer Affairs. Article in Press

Ashforth, B.E., and Mael, F. (1989). Social Identity Theory and the Organization. Academy of Management Review, 14(1), 20-39.

Ashforth, B.E., and Johnson, S.A. (2001). Which hat to wear? The relative salience of multiple identities in organizational contexts. In M.A.T. Hogg and D.J. Terry (Eds.), Social Identity Processes in Organizational Contexts. Philadelpia (pp. 31-48).

Psychology Press. 
576 Bagozzi, R.P., and Dholakia, U.M. (2006). Antecedents and purchase consequences of

6 customer participation in small group brand communities. International Journal of Research in Marketing, 23(1), 45-61.

Bartels, J., and Hoogendam, K. (2011). The role of social identity and attitudes toward sustainability brands in buying behavior for organic products. Journal of Brand Management, 18, 697-708.

Bartels J., and Reinders, M. (2010). Social identification, social representations, and consumer innovativeness in an organic food context: A cross-national comparison. Food Quality and Preference, 21, 347-352.

Bartels, J., and Reinders, M.J. (2016). Consuming apart, together: the role of multiple identities in sustainable behaviour. International Journal of Consumer Studies, 40, 444452.

Bauer, H. H., Heinrich, D., and Schäfer, D. B. (2013). The effects of organic labels on global, local, and private brands. More hype than substance? Journal of Business Research, 66(8), 1035-1043.

Bekk, M., Spörrle, M., Hedjasie, R., and Kerschreiter, R. (2016). Greening the competitive advantage: antecedents and consequences of green brand equity. Quality \& Quantity, 50(4), 1727-1746.

Bergami, M., and Bagozzi, R.P. (2000). Self-categorization, affective commitment and group self-esteem as distinct aspects of social identity in the organization. British Journal of Social Psychology, 39, 555-577.

Bhattacharya, C.B., Rao, H., and Glynn, M.A. (1995). Understanding the bond of identification: An investigation of its correlates among art museum members. Journal of Marketing, 59, 46-57. 
Bhattacharya, C.B., and Sen, S. (2003). Consumer-company identification: A framework for understanding consumers' relationships with companies. Journal of Marketing, 67, 76-88.

Biswas, A. (1992). The moderating role of brand familiarity in reference price perceptions. Journal of Business Research, 25(3), 251-262.

Calvo-Porral, C. and Lang, M. (2015). Private Labels: The role of manufacturer identification, brand loyalty and image on purchase intention. British Food Journal, 17(2), 506-522.

Chang, C.-H., and Chen, Y.-S. (2013). Managing green brand equity: the perspective of perceived risk theory. Quality \& Quantity, 48, 1753-1768.

Chen, Y.-S. (2010). The drivers of green brand equity: Green brand image, green satisfaction, and green trust. Journal of Business Ethics, 93, 307-319.

Chkanikova, O., and Lehner, M. (2015). Private eco-brands and green market development: towards new forms of sustainability in food retailing. Journal of Cleaner Production, 107, 74-84.

Cialdini, R.B., Borden, R.J., Thorne, A., Walker, M.R., Freeman, S., and Sloan, L.R. (1976). Basking in reflected glory: Three (football) field studies. Journal of Personality and Social Psychology, 34, 366-375.

Cobb-Walgren, C.J., Ruble, C.A., and Donthu, N. (1995). Brand equity, brand preference, and purchase intent. Journal of Advertising, 24(3), 25-40.

Cuneo, A., Lopez, P., and Yague, M. J. (2012). Private label brands: measuring equity across consumer segments. Journal of Product \& Brand Management, 21(6), 428-438.

Cuneo, A., Milberg, S. J., Benavente, J. M., and Palacios-Fenech, J. (2015). The growth of private label brands: A worldwide phenomenon. Journal of International Marketing, 23 (1), 73-90. 
Dean, M., Raats, M.M., and Shepherd, R. (2012). The role of self-identity, past behavior, and their interaction in predicting intention to purchase fresh and processed organic food. Journal of Applied Social Psychology, 42(3), 669-688.

Deloitte (2015). The 2015 American Pantry Study The call to re-connect with consumers. http://www2.deloitte.com/content/dam/Deloitte/us/Documents/consumer-business/us-cb2015-american-pantry-study.pdf

De Wulf, K., Odekerken-Schröder, G., Goedertier, F., and Van Ossel, G. (2005). Consumer perceptions of store brands versus national brands. Journal of Consumer Marketing, 22(4), 223-232.

Dholakia, U.M., Bagozzi, R.P., and Pearo, L.K. (2004). A social influence model of consumer participation in network- and small-group-based virtual communities. International Journal of Research in Marketing, 21(3), 241-263.

Ellis, J. L., McCracken, V. A., and Skuza, N. (2012). Insights into willingness to pay for organic cotton apparel. Journal of Fashion Marketing and Management, 16 (3), 290-305.

Erdem, T., Zhao, Y., and Valenzuela, A. (2004). Performance of store brands: A crosscountry analysis of consumer store-brand preferences, perceptions, and risk. Journal of Marketing Research, 41 (1), pp. 86-100.

Escalas, J.E., and Bettman, J.R. (2003). You are what they eat: The influence of reference groups on consumers' connections to brands. Journal of Consumer Psychology, 13(3), $339-348$.

Esch, F.-R., Langner, T., Schmitt, B. H., and Geus, P. (2006). Are brands forever? How brand knowledge and relationships affect current and future purchases. Journal of Product \& Brand Management, 15(2), 98-105 
Gleim, M.R., Smith, J.S., Andrews, D., and Cronin Jr., J.J. (2013). Against the green: A multi-method examination of the barriers to green consumption Journal of Retailing, 89(1), 44-61.

González-Benito, O., and Martos-Partal, M. (2012). Role of retailer positioning and product category on the relationship between store brand consumption and store loyalty. Journal of Retailing, 88 (2), 236-249.

Grewal, D., and Levy, M.(2009). Emerging issues in retailing research. Journal of Retailing, $85(4), 522-526$.

Griskevicius, V., Tybur, J.M., and Van den Bergh, B. (2010). Going Green to Be Seen:

Status, Reputation, and Conspicuous Conservation. Journal of Personality and Social Psychology, 98(3), 392-404.

Gupta, S., and Kumar, V. (2013). Sustainability as a corporate culture of a brand for superior performance. Journal of World Business, 8 (3), 311-320.

Hartmann, P., Apaolaza Ibáñez, V., and Forcada Sainz, F.J. (2005). Green branding effects on attitude: functional versus emotional positioning strategies. Marketing Intelligence \& Planning, 23 (1), pp. 9-29.

He, H., Li, Y., and Harris, L. (2012). Social identity perspective on brand loyalty. Journal of Business Research, 65, 648-657.

Homburg, C., Wieseke, J., and Bornemann, T. (2009). Implementing the marketing concept at the employee-customer interface: The role of customer need knowledge. Journal of Marketing, 73, 64-81.

Hughner, R.S., McDonagh, P., Prothero, A., Shultz II, C.J., and Stanton, J. (2007). Who are organic food consumers? A compilation and review of why people purchase organic food. Journal of Consumer Behavior, 6, 1-17. 
Jonas, A., and Roossen, J. (2005). Private labels for premium products - the example of organic food. International Journal of Retail \& Distribution Management, 33 (8), pp. 636-653.

Kang, S., and Hur, W.-M. (2012). Investigating the antecedents of green brand equity: A sustainable development perspective. Corporate Social Responsibility and Environmental Management, 19, 306-316.

Keller, K. L. (1993). Conceptualizing, Measuring, and Managing Customer-Based Brand Equity. Journal of Marketing, 57(1), 1-22.

Konuk, F. A., Rahman, S. U., and Salo, J. (2015). Antecedents of green behavioral intentions: a cross-country study of Turkey, Finland and Pakistan. International Journal of Consumer Studies, 39, 586-596.

Krystallis, A. (2015). Motivation and cognitive structures of store versus manufacturer brand consumers. Journal of Consumer Behavior, 14 (4), 270-284.

Kuenzel, S., and Halliday, S.V. (2008). Investigating antecedents and consequences of brand identification. Journal of Product \& Brand Management, 17(5), 293 - 304.

Lam, S.K., Ahearne, M., Hu, Y., and Schillewaert, N. (2010). Resistance to brand switching when a radically new brand is introduced: A social identity theory perspective. Journal of Marketing, 74(6), 128-146.

Larceneux, F., Benoit-Moreau, F., and Renaudin, V. (2012). Why might organic labels fail to influence consumer choices? Marginal labelling and brand equity effects. Journal of Consumer Policy, 35, 85-104.

Mael, F.A., and Ashforth, B.E. (1992). Alumni and their alma mater: A partial test of the reformulated model of organization identification. Journal of Organizational Behavior, $13(2), 103-123$. 
Mieres, C.G., Martín, A.M.D., and Gutiérrez, J.A.T. (2006). Antecedents of the difference in perceived risk between store brands and national brands. European Journal of Marketing, $40(1 / 2), 61-82$

Murtagh, N., Gatersleben, B., and Uzzell, D. (2012). Multiple identities and travel mode choice for regular journeys. Transportation Research Part F, 15, 514-524.

Netemeyer, R. G., Krishnan, B., Pullig, C., Wang, G., Yagci, M., Dean, D., Ricks, J., and Wirth, F. (2004). Developing and validating measures of facets of customer-based brand equity. Journal of Business Research, 57(2), 209-224.

Ng, P. F., Butt, M. M., Khong, K. W., and Ong, F. S. (2013). Antecedents of green brand equity: an integrated approach. Journal of Business Ethics, 1-13

Ngobo, P.-V. (2011). What drives household choice of organic products in grocery stores? Journal of Retailing, 87(1), 90-100.

Olbrich, R., and Jansen, H.C. (2014). Price-quality relationship in pricing strategies for private labels. Journal of Product and Brand Management, 23(6), 429-438.

Onwezen, M.C., Bartels, J., and Antonides G. (2014). The self-regulatory function of anticipated pride and guilt in a sustainable and healthy consumption context. European Journal of Social Psychology, 44,53-68.

Organic Trade Association (2013). Eight in Ten U.S. Parents Report They Purchase Organic Products. Available at https://www.ota.com/news/press-releases/17124, accessed July 2015.

Organic Trade Association (2015). U.S. Organic Industry Survey 2015. Available at https://ota.com/what-ota-does/market-analysis, accessed July 2015.

Papista, E., and Krystallis, A. (2013). Investigating the types of value and cost of green brands: Proposition of a conceptual framework. Journal of Business Ethics, 115 (1), 7592. 
719 Pickett-Baker, J., and Ozaki, R. (2008). Pro-environmental products: marketing influence on consumer purchase decision. Journal of Consumer Marketing, 25 (5), 281 - 293.

Podsakoff P. M., MacKenzie S. B., Lee J. Y, and Podsakoff, N. P. (2003). Common method biases in behavioral research: a critical review of the literature and recommended remedies. Journal of Applied Psychology, 88(5), 879-903.

Pratt, M.G., and Foreman, P.O. (2000). Classifying managerial responses to multiple organizational identities. The Academy of Management Review, 25(1), 18-42.

Preacher, K. J., and Hayes, A. F. (2008). Asymptotic and resampling strategies for assessing and comparing indirect effects in multiple mediator models. Behavior research methods, 40(3), 879-891.

Rödiger, M., and Hamm, U. (2015). How are organic food prices affecting consumer behaviour? A review. Food Quality and Preference, 43, 10-20.

Schifferstein, H.N. J., and Oude Ophuis, P.A.M. (1998). Health-related determinants of organic food consumption in the Netherlands. Food Quality and Preference, 9(3), 119133.

Sethuraman, R., and Gielens, K. (2014). Determinants of store brand share. Journal of Retailing, 90(2), 141-153.

Stanton, J.V., and Guion, D.T. (2015). Perceptions of "organic" food: A view through brand theory. Journal of International Food \& Agribusiness Marketing, 27(2), 120-141.

Statista (2014). Market share of private label brands worldwide in 2013, by selected country. Available at http://www.statista.com/statistics/244903/market-share-of-private-labelbrands-worldwide-by-selected-country, accessed July 2015.

741 Steenkamp, J. B. E. M., and Baumgartner, H. (1998). Assessing measurement invariance in cross-national consumer research. Journal of Consumer Research, 25(1), 78-90. 
Steenkamp, J. B. E. M., van Heerde, H.J., and Geyskens, I. (2010). What makes consumers willing to pay a price premium for national brands over private labels? Journal of Marketing Research, 47, $1011-1024$.

Stokburger-Sauer, N., Ratneshwar, S., and Sen, S. (2012). Drivers of consumer-brand identification. International Journal of Research in Marketing, 29, 406-418.

Stryker, S., and Burke, P. J. (2000). The past, present, and future of an identity theory. Social Psychology Quarterly, 63(4), 284-297.

Tajfel, H. (1978). Social categorisation, social identity and social comparison. In H. Tajfel (Ed.), Differentiation Between Social Groups: Studies in the Social Psychology of InterGroup Relations (pp. 61-76). London: Academic Press.

Tajfel, H., and Turner, J. C. (1979). An integrative theory of intergroup conflict. In W. G. Austin and S. Worchel (Eds.), The social psychology of intergroup relations (pp. 33-47). Monterey, CA: Brooks/Cole.

Textile Exchange (2014). Organic Cotton Market Report 2014. Available at http://textileexchange.org/resource-center/media-room/2014-organic-cotton-report, accessed July 2015.

Tuškej, U., Golob, U., and Podnar, K. (2013). The role of consumer-brand identification in building brand relationships. Journal of Business Research, 66(1), 53-59.

van Dick, R., Christ, O., Stellmacher, J., Wagner, U., Ahlswede, O., Grubba, C., Hauptmeier, M., Höhfeld, C., Moltzen, K., and Tissington, P. A. (2004). Should I stay or should I go? Explaining turnover intentions with organizational identification and job satisfaction. British Journal of Management, 15(4), 351-360.

765 Willer, H. and Kilcher, L. (2010), The World of Agriculture. Statistics and Emerging Trends, IFOAM, FiBL, Frick, Bonn. 
767 Yoo, B., Donthu, N., and Lee, S. (2000). An examination of selected marketing mix elements 1 768 and brand equity. Journal of the Academy of Marketing Science 28(2): 195-211.

569 Yoo, B., and Donthu, N. (2001). Developing and validating a multidimensional consumer770 based brand equity scale. Journal of Business Research, 52, 1-14. 
Table 1: Sample characteristics

\begin{tabular}{|c|c|c|c|c|c|c|}
\hline & $\begin{array}{l}\text { Total study } \\
\text { population } \\
(\mathrm{N}=706)\end{array}$ & $\begin{array}{l}\text { The } \\
\text { Netherlands } \\
(\mathrm{N}=\mathbf{1 6 0})\end{array}$ & $\begin{array}{l}\text { Germany } \\
(N=171)\end{array}$ & $\begin{array}{l}\text { United States } \\
(N=178)\end{array}$ & $\begin{array}{l}\text { Canada } \\
(N=119)\end{array}$ & $\begin{array}{l}\text { Australia } \\
(\mathrm{N}=78)\end{array}$ \\
\hline Age (mean) & 49.5 years & 52.1 years & 48.8 years & 49.1 years & 46.5 years & 51.6 years \\
\hline \multicolumn{7}{|l|}{ Gender: } \\
\hline Male & $50.1 \%$ & $43.1 \%$ & $50.9 \%$ & $53.4 \%$ & $50.4 \%$ & $55.1 \%$ \\
\hline Female & $49.9 \%$ & $56.9 \%$ & $49.1 \%$ & $46.6 \%$ & $49.6 \%$ & $44.9 \%$ \\
\hline \multicolumn{7}{|l|}{ Education: } \\
\hline $\begin{array}{l}\text { Low level (i.e., primary education } \\
\text { or secondary education ) }\end{array}$ & $18.6 \%$ & $35.6 \%$ & $27.5 \%$ & $11.2 \%$ & $4.2 \%$ & $2.6 \%$ \\
\hline $\begin{array}{l}\text { Medium level (i.e., vocational } \\
\text { education) }\end{array}$ & $47.5 \%$ & $35.6 \%$ & $43.9 \%$ & $51.7 \%$ & $47.9 \%$ & $69.2 \%$ \\
\hline $\begin{array}{l}\text { High level (i.e., college or } \\
\text { university) }\end{array}$ & $34.0 \%$ & $28.7 \%$ & $28.7 \%$ & $37.1 \%$ & $47.9 \%$ & $28.2 \%$ \\
\hline \multicolumn{7}{|l|}{ Income: } \\
\hline Low income & $25.6 \%$ & $29.4 \%$ & $31.6 \%$ & $23.6 \%$ & $19.3 \%$ & $19.2 \%$ \\
\hline Medium income & $32.0 \%$ & $34.4 \%$ & $35.7 \%$ & $28.7 \%$ & $25.2 \%$ & $37.2 \%$ \\
\hline High income & $30.6 \%$ & $13.1 \%$ & $21.6 \%$ & $43.3 \%$ & $45.4 \%$ & $34.6 \%$ \\
\hline Will not say & $11.8 \%$ & $23.1 \%$ & $11.1 \%$ & $4.5 \%$ & $10.1 \%$ & $9.0 \%$ \\
\hline $\begin{array}{l}\text { Organic brand consumption PLB } \\
\text { Measured on a scale } 1 \text { (never) to } 5 \text { (five times a } \\
\text { week or more); standard deviation in brackets }\end{array}$ & $1.73(.98)$ & $1.84(1.02)$ & $1.62(.94)$ & $1.56(.97)$ & $2.03(.97)$ & $1.80(.92)$ \\
\hline $\begin{array}{l}\text { Organic brand consumption NB } \\
\text { Measured on a scale } 1 \text { (never) to } 5 \text { (five times a } \\
\text { week or more); standard deviation in brackets }\end{array}$ & $1.62(.95)$ & $1.70(1.01)$ & $1.77(.97)$ & $1.44(.88)$ & $1.74(1.03)$ & $1.15(.44)$ \\
\hline $\begin{array}{l}\text { Organic consumption behavior } \\
\text { Measured on a scale } 1 \text { (never) to } 5 \text { (five times a } \\
\text { week or more); standard deviation in brackets }\end{array}$ & $1.99(1.00)$ & $1.95(.97)$ & $2.26(1.03)$ & $1.88(.96)$ & $1.93(1.01)$ & $1.86(.96)$ \\
\hline
\end{tabular}


Table 2: Descriptive results
M
SD
1.
2.
3.
4.
5.

\section{PLBs $(N=404)$}

1. Organic consumption behavior

$2.05 \quad 1.00$

2. Organic brand consumption

$1.73 \quad .98$

$.56^{* *}$

3. Brand equity

$2.74 \quad .96$

$.43 * *$

$.48 * *$

4. Identification organic consumer

1.00

$.48 * *$

$.31 * *$

$.43 * *$

5. Brand identification

2.07

.96

$.45 * *$

$.45^{* *}$

$.61 * *$

$.64^{* *} \quad--$

6. Organic product familiarity

$3.06 \quad .82$

$.45 * *$

$.26 * *$

$.43 * *$

$.54 * *$

$.38 * *$

NBs $(N=302)$

1. Organic consumption behavior

2. Organic brand consumption

$1.92 \quad .99$

$1.62 \quad .95$

$2.58 \quad 1.07$

$.70 * *$

3. Brand equity

4. Identification organic consumer

2.15

.94

$.45^{* *}$

$.52 * *$

$.54 * *$

$.45 * *$

$.48^{* *}$

5. Brand identification

2.00

6. Organic product familiarity
$1.03 \quad .50 * *$

$.52 * *$

$.69 * *$

$.49 * *$
$.48^{* *} \quad .49 * *$
$.64 * * \quad--$ 
Table 3: Drivers of organic brand consumption for PLBs

\begin{tabular}{|c|c|c|c|c|c|c|c|c|}
\hline & \multicolumn{4}{|c|}{ Organic brand consumption (T2) } & \multicolumn{4}{|c|}{ Organic consumption behavior (T2) } \\
\hline & Model 1 & Model 2 & Model 3 & Model 4 & Model 5 & Model 6 & Model 7 & Model 8 \\
\hline Brand equity & $.43 * *$ & $.29 * *$ & $.29 * *$ & $.29 * *$ & $.31 * *$ & $.16^{*}$ & $.16^{* *}$ & $.16^{* *}$ \\
\hline Brand identification & -- & $.24 * *$ & $.27 * *$ & $.26 * *$ & -- & $.26 * *$ & $.16^{*}$ & $.16^{*}$ \\
\hline Organic consumer identification & -- & -- & -.05 & -.06 & -- & -- & $.19 * *$ & $.19 * *$ \\
\hline Organic product familiarity & .10 & .07 & .08 & .07 & $.30 * *$ & $.26 * *$ & $.20 * *$ & $.20 * *$ \\
\hline Brand equity $\mathrm{X}$ Brand identification & -- & -- & -- & .01 & -- & -- & -- & .02 \\
\hline Brand equity X Organic consumer identification & -- & -- & -- & .10 & -- & -- & -- & -.04 \\
\hline Income & .04 & .04 & .04 & .03 & .07 & .07 & .07 & .08 \\
\hline Education & -.01 & -.02 & -.02 & -.02 & .06 & .05 & .04 & .03 \\
\hline Age & .01 & .01 & .02 & .01 & .02 & .02 & .02 & .02 \\
\hline Gender & -.01 & -.02 & -.02 & -.03 & .06 & .05 & .05 & .05 \\
\hline Country Netherlands & .05 & .05 & .05 & .05 & .05 & .05 & .05 & .05 \\
\hline Country Germany & -.06 & -.07 & -.08 & -.07 & .07 & .06 & .07 & .07 \\
\hline Country Australia & .06 & .06 & .06 & .06 & .03 & .04 & .04 & .04 \\
\hline Country Canada & .04 & .07 & .07 & .08 & -.02 & .00 & .01 & .01 \\
\hline$N$ & 404 & 404 & 404 & 404 & 404 & 404 & 404 & 404 \\
\hline $\mathrm{R}^{2}$ & .25 & .28 & .28 & .29 & .29 & .33 & .34 & .35 \\
\hline$F$ Value & $11.40 * *$ & $12.34 * *$ & $11.35 * *$ & $10.16 * *$ & $14.05 * *$ & $15.33 * *$ & $15.13 * *$ & $12.96 * *$ \\
\hline
\end{tabular}


Table 4: Drivers of organic brand consumption for NBs

\begin{tabular}{|c|c|c|c|c|c|c|c|c|}
\hline & \multicolumn{4}{|c|}{ Organic brand consumption (T2) } & \multicolumn{4}{|c|}{ Organic consumption behavior (T2) } \\
\hline & Model 1 & Model 2 & Model 3 & Model 4 & Model 5 & Model 6 & Model 7 & Model 8 \\
\hline Brand equity & $.40 * *$ & $.27 * *$ & $.27 * *$ & $.28 * *$ & $.33 * *$ & $.20 * *$ & $.20 * *$ & $.20 * *$ \\
\hline Brand identification & -- & $.22 * *$ & .14 & .12 & -- & $.21 * *$ & .04 & .03 \\
\hline Organic consumer identification & -- & -- & $.16^{*}$ & $.17 *$ & -- & -- & $.31 * *$ & $.32 * *$ \\
\hline Organic product familiarity & $.23^{* *}$ & $.19 * *$ & $.15^{*}$ & $.16^{*}$ & $.34 * *$ & $.31 * *$ & $.23 * *$ & $.24 * *$ \\
\hline Brand equity $X$ Brand identification & -- & -- & -- & -.07 & -- & -- & -- & -.03 \\
\hline Brand equity X Organic consumer identification & -- & -- & -- & .13 & -- & -- & -- & .08 \\
\hline Income & -.09 & -.09 & -.09 & -.09 & .05 & .05 & .05 & .05 \\
\hline Education & .09 & .08 & .08 & .08 & .04 & .03 & .03 & .03 \\
\hline Age & .10 & .09 & .09 & .10 & .03 & .02 & .03 & .03 \\
\hline Gender & .05 & .05 & .04 & .05 & .05 & .04 & .03 & .03 \\
\hline Country Netherlands & -.01 & .00 & .01 & .01 & $-.15^{*}$ & $-.14^{*}$ & $-.13 *$ & $-.12 *$ \\
\hline Country U.S. & .02 & .02 & .02 & .02 & .00 & .00 & -.01 & -.01 \\
\hline Country Australia & -.02 & .01 & .00 & .01 & -.02 & -.01 & -.03 & -.02 \\
\hline Country Canada & .03 & .06 & .06 & .06 & $-.16^{*}$ & $-.14 *$ & $-.13 *$ & $-.13 *$ \\
\hline$N$ & 302 & 302 & 302 & 302 & 302 & 302 & 302 & 302 \\
\hline $\mathrm{R}^{2}$ & .33 & .35 & .37 & .38 & .36 & .38 & .43 & .43 \\
\hline$F$ Value & $12.44 * *$ & $12.47 * *$ & $12.03 * *$ & $10.67 * *$ & $14.09 * *$ & $13.99 * *$ & $15.81 * *$ & $13.65 * *$ \\
\hline
\end{tabular}

